\title{
Ecological assessment of a southeastern Brazil reservoir
}

\author{
Isabela Martins', Barbara Sanches ${ }^{2}$, Philip Robert Kaufmann ${ }^{3}$, Robert M. Hughes ${ }^{4}$, \\ Gilmar Bastos Santos ${ }^{2}$, Joseline Molozzi ${ }^{5}$ \& Marcos Callisto ${ }^{1,6}$ \\ ${ }^{1}$ Departamento de Biologia Geral, Universidade Federal de Minas Gerais, Belo Horizonte, MG, Brazil. \\ ${ }^{2}$ Programa de Pós-graduação em Zoologia de Vertebrados, Pontifícia Universidade Católica de Minas \\ Gerais, Belo Horizonte, MG, Brazil. \\ ${ }^{3}$ Western Ecology Division, United States Environmental Protection Agency, Corvallis, OR, United States. \\ ${ }^{4}$ Amnis Opes Institute and Department of Fisheries and Wildlife, Oregon State University, Corvallis, OR, \\ United States. \\ ${ }^{5}$ Departamento de Biologia Geral, Universidade Estadual da Paraiba, Campina Grande, PB, Brazil. \\ ${ }^{6}$ Corresponding author: Marcos Callisto, e-mail: mcallisto13@gmail.com
}

MARTINS, I., SANCHES, B., KAUFMANN, P.R., HUGHES, R.M., SANTOS, G.B., MOLOZZI, J., CALLISTO, M. Ecological assessment of a southeastern Brazil reservoir. Biota Neotropica. 15(1): e20140061. http://dx.doi.org/10.1590/1676-06032015006114

\begin{abstract}
Reservoirs are artificial ecosystems with multiple functions having direct and indirect benefits to humans; however, they also cause ecological changes and influence the composition and structure of aquatic biota. Our objectives were to: (1) assess the environmental condition of Nova Ponte Reservoir, Minas Gerais state, southeastern Brazil; and (2) determine how the aquatic biota respond to disturbances. A total of 40 sites in the littoral zone of the reservoir were sampled to characterize physical and chemical habitat, land use, and benthic macroinvertebrate and fish assemblages. The predominant type of land cover near the reservoir was natural vegetation. A total of 29 fish species and 39 macroinvertebrate taxa were collected, including eight alien species. Most sites had intermediate levels of human disturbance, however, high levels of degradation were associated with high proportions of alien species. Disturbances at multiple scales may alter natural patterns and processes, leading to environmental changes and damaging biological communities. Our results reinforce the importance of assessing reservoir ecological conditions at several scales. The study of land use, littoral zone physical habitat characteristics, water quality, and assemblage structure set the ground for proposing actions to rehabilitate and conserve aquatic ecosystems.
\end{abstract}

Keywords: reservoirs, water quality, bioindicators, physical habitat, environmental quality.

MARTINS, I., SANCHES, B., KAUFMANN, P.R., HUGHES, R.M., SANTOS, G.B., MOLOZZI, J., CALLISTO, M. Avaliação Ecológica de um reservatório no sudeste do Brasil. Biota Neotropica. 15(1): e20140061. http://dx.doi.org/10.1590/1676-06032015006114

Resumo: Reservatórios são ecossistemas artificiais com múltiplas funções e que oferecem benefícios diretos e indiretos ao homem; no entanto, também causam mudanças ecológicas e influenciam a composição e estrutura da biota aquática. Os objetivos deste estudo foram: (1) avaliar a condição ambiental do reservatório de Nova Ponte, Estado de Minas Gerais, sudeste do Brasil; e (2) verificar se a biota aquática responde aos distúrbios. No total, 40 sítios amostrais na região litorânea do reservatório foram amostrados para caracterizar os habitats físicos e químicos, cobertura e uso do solo, assembleias de macroinvertebrados e peixes. Vegetação natural de cerrado foi o tipo predominante de cobertura do solo no entorno do reservatório. 29 espécies de peixes e 39 taxa de macroinvertebrados bentônicos foram coletadas, incluindo oito espécies exóticas. A maioria dos sítios amostrais possui níveis intermediários de distúrbio antrópico, porém o aumento de alterações antrópicas foi associado ao aumento do número e abundância de espécies exóticas. Distúrbios em múltiplas escalas podem alterar os padrões e processos naturais, levando a mudanças ambientais e nas comunidades biológicas. Nossos resultados reforçam a importância de avaliar as condições ecológicas do reservatório em várias escalas. $\mathrm{O}$ estudo do uso e cobertura do solo, características de habitats físicos na zona litorânea, características limnológicas e estrutura das assembléias fornecem bases para a proposição de ações para reabilitação e conservação de ecossistemas aquáticos.

Palavras-chave: Reservatórios, bioindicadores de qualidade de água, habitats físicos, qualidade ambiental. 


\section{Introduction}

Reservoirs are artificial ecosystems with multiple functions, such as water storage, flood control, and electricity generation (Tundisi \& Matsumura-Tundisi 2008). Their multiple uses bring indirect benefits to society, including economic development, employment, and income generation (Tundisi \& Matsumura-Tundisi 2008). Reservoirs have become one of the most common types of human alteration in Brazilian river basins, where nearly all large rivers are dammed (von Sperling 2012). Dams produce several changes in rivers, including altered flow regimes, substrate composition, riparian flooding patterns, and riparian plant cover (Franklin et al. 1995). Those changes in turn influence fish and macroinvertebrate assemblage structure and composition (Agostinho et al., 2008, Borges et al. 2010), and may interfere with aquatic food web functions (Maroneze et al. 2011).

Aquatic species in reservoirs may be affected by human impacts at local and landscape scales (Luiz et al. 2003). Land use near reservoirs directly affects water quality (Beavan et al. 2001), which affects the density, distribution, and richness of biological communities. Therefore, it is necessary to assess the surrounding land use to evaluate ecological conditions of aquatic ecosystems in a meaningful manner (Meyer \& Turner 1994). In urban reservoirs, for example, there are intensive human modifications in adjacent areas resulting from roads, housing, and commercial/industrial development (Hughes et al. 2014). Physical habitat modifications directly influence the composition and structure of aquatic communities (Kaufmann et al. 2014), and alter organism diets, reproduction, and growth (Benedito-Cecílio et al. 1997). As a result of all these influences, and because of the dam itself, aquatic communities undergo changes (Gehrke et al. 2002, Agostinho et al. 2008) that favor biological invasion (Rocha et al. 2011).

Information about land use and cover, littoral zone physical and chemical habitat characteristics, and aquatic assemblage structure facilitate ecological condition assessments and actions for rehabilitating and conserving aquatic ecosystems (Hughes et al. 2014, Kaufmann et al. 2014). This approach is particularly important in river basins with hydroelectric power plants (Macedo et al. 2012).

Our objective was to assess the ecological condition of Nova Ponte Reservoir in terms of its surrounding land use, littoral physical and chemical habitat, and fish and benthic macroinvertebrate assemblage structure. We hypothesized that reservoir macroinvertebrate and fish assemblages would respond to habitat disturbance and water characteristics.

\section{Methods}

\section{Study area}

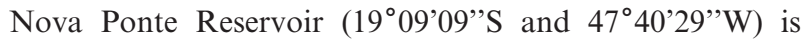
located on the Araguari and Quebra-Anzol Rivers in the state of Minas Gerais, southeastern Brazil, in the Paraná River basin, and was built to generate electricity (Figure 1). The local climate is tropical with temperatures between $14{ }^{\circ} \mathrm{C}$ and $30{ }^{\circ} \mathrm{C}$ and average annual rainfall of ca. 1,700 mm (Durães et al. 2001). There is a dry season from April to September (minimum rainfall of $11 \mathrm{~mm} / \mathrm{month}$ ) and a rainy season from October to March (maximum rainfall of $280 \mathrm{~mm} / \mathrm{month}$ ) (Climatempo 2013). The predominant vegetation is neotropical savanna (cerrado). Nova Ponte Reservoir is the largest of a series of reservoirs on the Araguari River, with a depth of 120 $\mathrm{m}$ close to the dam, a length of $115 \mathrm{~km}$, and a volume of 12.8 billion $\mathrm{m}^{3}$ (Vono 2002). Its hydroelectric power plant has a capacity of $510 \mathrm{Mw}$, three generating units, and its dam is 141 $\mathrm{m}$ high and 1,600 m long. The floodgates closed in 1993 and operations began in 1994 (CEMIG 2013).

1.1 Study design. The sampling sites were defined according to the concept of spatially balanced sampling (Stevens \& Olsen 2004) adapted to large reservoirs (Macedo et al. 2014). The reservoir's perimeter was divided into 40 equidistant sections based on a randomly defined first point. Each site was located at the beginning of each section and each site was $200 \mathrm{~m}$ long. In each of the 40 sites, we assessed physical and chemical habitat, and sampled benthos and fish at the end of the rainy season, in April 2010. We did not conduct any temporal replication because of financial limits and a focus on spatial patterns.

\section{Habitat characterization}

2.1. Land use. We assessed land use via satellite images (TM sensor onboard Landsat 5 and images from Google Earth 6.0) that were obtained during the sampling period. We determined buffer areas of $500 \mathrm{~m}$ around each sampling site. Within each buffer, polygons were delimited and used to quantify the cover percentage of each land use and cover category. To visualize and determine the different types of land uses, we employed Kosmo 2.0 (Open Geographic Information System).

2.2 Physical habitat structure. In each of the 40 sites, we recorded cover percentage of aquatic macrophytes and types of substrates in the littoral zone, riparian vegetation features, and type and intensity of human impacts in the riparian zone (USEPA 2011). In each of the sites, we applied the physical habitat protocol along $200 \mathrm{~m}$ of the reservoir margin, in 10 consecutive, equidistant sample units (plots). Each plot comprised parts of the littoral $(15 \times 10 \mathrm{~m})$, riparian $(15 \times 15 \mathrm{~m})$, and exposed littoral zones (15 $\mathrm{m}$ wide and variable depth).

2.3. Water and sediment character. We used a multiparameter meter (model YSI 6600) to measure temperature $\left({ }^{\circ} \mathrm{C}\right), \mathrm{pH}$, electrical conductivity $\left(\mu \mathrm{S} \mathrm{cm}^{-1}\right)$, and total dissolved solids $\left(\mathrm{g} \mathrm{L}^{-1}\right)$. We measured total depth with a SONAR gauge, euphotic zone depth with a Secchi disk, and turbidity (NTU) with a Digimed turbidimeter. We analyzed chlorophyll-a content $\left(\mu \mathrm{g} \mathrm{L}^{-1}\right)$ following Golterman et al. (1978), dissolved oxygen content (mg L $\mathrm{m}^{-1}$ and percent saturation) according to Winkler (1888), and total alkalinity $\left(\mathrm{mg} \mathrm{L}^{-1}\right)$ by the GRAN method (Carmouze 1994). We determined total nitrogen (ug $\mathrm{L}^{-1}$ ) and total phosphorous (TP, ug $\mathrm{L}^{-1}$ ) according to Golterman et al. (1978) and Mackereth et al. (1978), respectively.

We calculated a trophic state index (TSI) as proposed by the Sanitation Company of São Paulo State (Companhia de Tecnologia de Saneamento Ambiental - CETESB 2004) for each of the 40 sites. The TSI and its component indices were calculated as follows:

$$
\begin{aligned}
& \text { TSI }=[\text { TSI }(\text { TP })+\text { TSI }(\mathrm{Chl})] / 2 ; \\
& \text { TSI }(\text { TP })=10 \times(6-(1.77-0.42 \times(\ln \text { TP }) / \ln 2)) ; \text { and } \\
& \text { TSI }(C h l)=10 \times(6-((0.92-0.34 \times(\ln C h l)) / \ln 2))
\end{aligned}
$$

We measured sediment organic matter content through calcination in a muffle furnace at $550{ }^{\circ} \mathrm{C}$ for $4 \mathrm{~h}$ (Esteves et al. 
${ }^{47} 7^{\circ} 30^{\circ} \mathrm{W}$ $47^{\circ} 00 \mathrm{~W}$

I

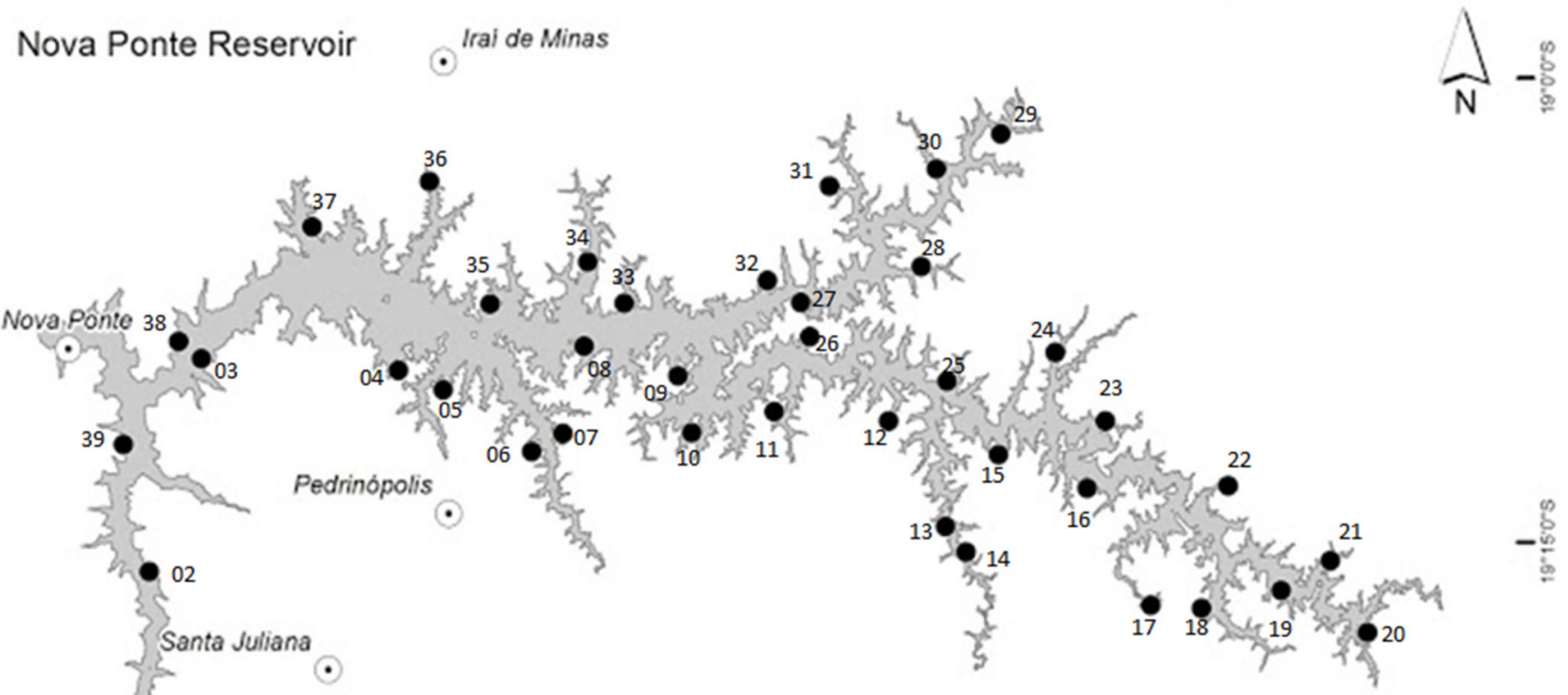

Figure 1. Location of 40 sampling sites on Nova Ponte Reservoir, in the Araguari river basin, Minas Gerais.

1995) and granulometric composition by sieving, following Suguio (1973) as modified by Callisto \& Esteves (1996).

2.4. Human disturbance. To evaluate the level of human disturbance at the sites, we applied the IDI (Integrated Disturbance Index) of Ligeiro et al. (2013), which was calculated from a Buffer Disturbance Index (BDI) and a Local Disturbance Index (LDI). We calculated the BDI according to the intensity of the disturbance in the $500 \mathrm{~m}$ buffer area as follows:

$\mathrm{BDI}=(4 \times \%$ residential construction area $)+2 \times(\%$ agricultural area $+\%$ bare soil area $)+(\%$ pasture area $)$.

We used the RDis_IX index of Kaufmann et al. (2014) to calculate the LDI. We incorporated human disturbances in both riparian and drawdown areas along with horizontal drawdown distance (Table1) in the calculation of RDis_IX (Kaufmann, unpublished data).

To incorporate the BDI and LDI into the IDI we first plotted the BDI and LDI scores for each site on a biplot, then we calculated the Euclidean distance of the position of the site relative to the graph origin. This was performed through application of the Pythagorean theorem: IDI $=\left[(\mathrm{LDI} / 2.25)^{2}+\right.$ $\left.(\mathrm{BDI} / 3)^{2}\right]^{1 / 2}$. The greater the site IDI value, the greater its deviation from the graph origin and the greater the level of disturbance (Ligeiro et al. 2013).

\section{Biological assemblage sampling}

3.1 Benthic macroinvertebrates. We collected macroinvertebrates in the littoral zone of each site with an Eckman-Birge grab $\left(0.0225 \mathrm{~cm}^{2}\right)$. The samples were stored in plastic bags, fixed in $10 \%$ formalin, and then washed in a sieve $(0.5 \mathrm{~mm}$ mesh $)$ in the laboratory. The organisms were identified to family under a stereo-microscope using Pérez (1988), Merritt \& Cummins (1996), Fernández \& Domínguez (2001), Costa et al. (2006), Mugnai et al. (2010), and Trivinho-Strixino (2011), and the Chironomidae were identified to genera. Then they were fixed in $70 \%$ alcohol and deposited in the Benthic Ecology Laboratory reference collection (França \& Callisto 2007), Institute of Biological Sciences, Federal University of Minas Gerais. We considered alien species as those that occurred outside their past or present natural geographic range, and whose dispersal is aided by humans (Falk-Petersen et al. 2006).

3.2 Fish. We sampled fish through use of gillnets with mesh sizes between 3 and $16 \mathrm{~cm}$ (distance between opposite knots), heights ranging between 1.6 and $1.8 \mathrm{~m}$, and lengths of $20 \mathrm{~m}$. At each sampling site, we placed a set of five pairs of nets in the late afternoon and removed them the following morning, with a total exposure time of approximately $15 \mathrm{~h}$. In the field, the captured specimens were separated by mesh size and sampling site, labeled, fixed in $10 \%$ formalin, placed in plastic drums, and 
Martins, I. et al.

Table 1. Metrics used to calculate the LDI (Local Disturbance Index), calculated based on Ligeiro, et al. (2013).

\begin{tabular}{|c|c|c|c|c|}
\hline Metric & Description & Min & Med & Max \\
\hline Pdraw & Ratio of horizontal drawdown distance divided by the field plot size $(15 \mathrm{~m})$. & 0.4 & 0.8 & 1.0 \\
\hline rviWoody & Summed coverage of woody vegetation in the canopy, understory and ground cover. & 0.0 & 0.7 & 0.9 \\
\hline$r v f c$ CanBig & Mean proportional areal cover of large diameter trees averaged over the 10 plots. & 0.0 & 0.0 & 0.0 \\
\hline rvfcGrdBare & Mean proportional areal cover of bare ground (soil) averaged over the 10 plots. & 0.0 & 1.0 & 1.0 \\
\hline hifpAnyCirca & Proportion of plots with at least one type of human activity. & 0.0 & 0.3 & 0.7 \\
\hline hiiAg & Proportion of plots with agricultural activities. & 0.0 & 0.1 & 0.3 \\
\hline hiiNonAg & Proportion of plots with non-agricultural activities. & 0.0 & 0.3 & 0.9 \\
\hline hiiAll & Sum of the proportions of plots with agricultural and non-agricultural activities. & 0.0 & 0.3 & 1.0 \\
\hline hiiAllCirca & Proportion between agricultural and non-agricultural activities. & 0.2 & 0.9 & 1.0 \\
\hline
\end{tabular}

transported to the Ichthyology Laboratory at Pontifícia Universidade Católica de Minas Gerais for sorting, biometry, and identification.

In the laboratory, we washed the fish in water and identified them to species through use of Britski et al. (1986) and Graça \& Pavanelli (2007). The individuals that were difficult to identify as well as part of the collected material were deposited as vouchers in the Ichthyological Collection of the State University of São José do Rio Preto, São Paulo, Brazil. We considered as alien species those from other river basins or those that originally did not belong to this reach of the Upper Paraná River (Oliveira et al. 2003, Graça \& Pavanelli, 2007).

\section{Data analyses}

4.1 Spatial autocorrelation assessment. To assess spatial autocorrelation between sampling sites, we applied Mantel tests (Mantel 1967) on Bray-Curtis similarity analyses of macroinvertebrate and fish abundance data in PAST software (Hammer et al. 2003). We calculated dissimilarity matrices from the geographic coordinates (Euclidean distance) of each site. The value of the test is the Pearson correlation coefficient $(\mathrm{R})$ between the two matrices. The significance of the test was generated by comparing the $\mathrm{R}$ value with the $\mathrm{R}$ value estimated from 10,000 randomly generated permutations from the biological samples.

4.3. Biotic metrics. For benthos, we calculated the following metrics: total abundance, family richness, Chironomidae abundance and genera richness, number and percentage of EPT (Ephemeroptera, Plecoptera and Trichoptera) individuals and taxa, number and percentage of resistant individuals and taxa, number and percentage of alien individuals and taxa, and number and percentage of tolerant individuals and taxa.

The fish metrics employed were total number of species, total number of native species, number and percentage of alien species, number and percentage of migratory species, number and percentage of rheophilic species, abundance and percentage of native individuals, percentage of species that account for $90 \%$ of total abundance, abundance and percentage of rheophilic individuals, catch per unit effort of individuals (CPUEn), catch per unit effort of native species (CPUEnNat), catch per unit effort of alien species (CPUEnExot), and percentage catch per unit effort of alien individuals ( $\%$ CPUEnAlien).

4.4 Influence of anthropogenic disturbance on biological assemblages. To assess the influence of human disturbances around the reservoir on benthic macroinvertebrate and fish assemblages, we made scatterplots and regressed biological metrics against the IDI, in Statistica 8.0 (StatSoft Inc. 2007). Prior to those analyses, metrics that comprised abundance and richness data were $\log (\mathrm{x}+1)$ transformed. Biotic metrics expressed as percentages and IDI values were arcsine square root transformed (Legendre \& Legendre 1998, Zar 1996).

4.5 Influence of water quality on biological assemblages. Initially, redundant biotic and abiotic variables were excluded $(r>0.7)$ through use of Spearman Rank Correlation. If only two variables were correlated, the one with higher average correlation coefficient was excluded from further analysis (Feld \& Hering 2007, Hughes et al. 2009, Raposeiro et al. 2011). We then performed an RDA (Redundancy Analysis) on the selected environmental variables standardized by Statistica 8.0 (StatSoft Inc. 2007) and biological metrics transformed as described above. For this, we used R 2.15.1 (R Core Team 2008).

\section{Results}

\section{Biological assemblages}

1.1 Benthic macroinvertebrates. We collected 1,116 organisms and 39 taxa, dominated by Chironomidae (46\%) and Oligochaeta $(42 \%)$ (Figure $2 \mathrm{a})$. Among the Chironomidae, we found 462 individuals and identified 21 genera (Figure 2b), dominated by Tanytarsus (van der Wulp 1984) (46\%) and Polypedilum (Kieffer 1913) (15\%). In the sites located in the buffer region of rivers and tributaries (24, 29, and 30) we observed the highest richness (6 and 7) of benthic taxa. The sampling sites with lowest richness (1 to 3 ) were located close to the dam (sites 2, 3, 37, 38, 39 and 40). We also collected nonnative Corbicula fluminea (Müller 1974) (Corbiculidae, Bivalvia) and Melanoides tuberculatus (Müller 1974) (Thiaridae, Gastropoda) near the dam (sites 01, 02, 37, 38, 39, and 40), and Macrobrachium amazonicum (Heller 1862) (Decapoda) in some sites.

1.2 Fish. We captured 2,463 individuals representing 5 orders, 13 families, and 29 species. Three species were migratory: Leporinus obtusidens (Valenciennes 1836), Salminus hilarii (Valenciennes 1850), and Prochilodus lineatus (Valenciennes 1836), representing only $2.2 \%$ of the abundance; and five were non-native: Oreochromis niloticus (Linnaeus 1758), Tilapia rendalli (Boulenger 1897), Pygocentrus nattereri (Kner 1858), Cichla piquiti (Kullander \& Ferreira 2006), and Metynnis lippincottianus (Cope 1870). The most abundant species were: Iheringichthys labrosus (Lütken 1874), Pimelodus maculatus (Lacepède 1803), Astyanax fasciatus (Cuvier 1829), Schizodon nasutus (Kner 1858), and Galeocharax knerii (Steindachner 


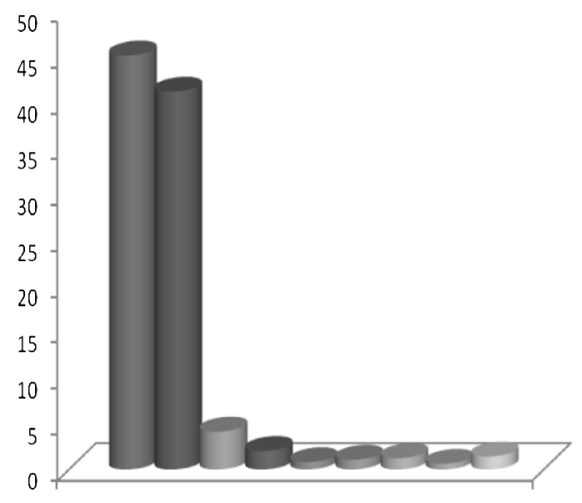

Percentage of individuals

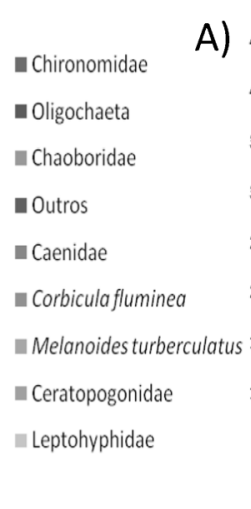

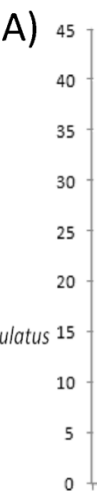

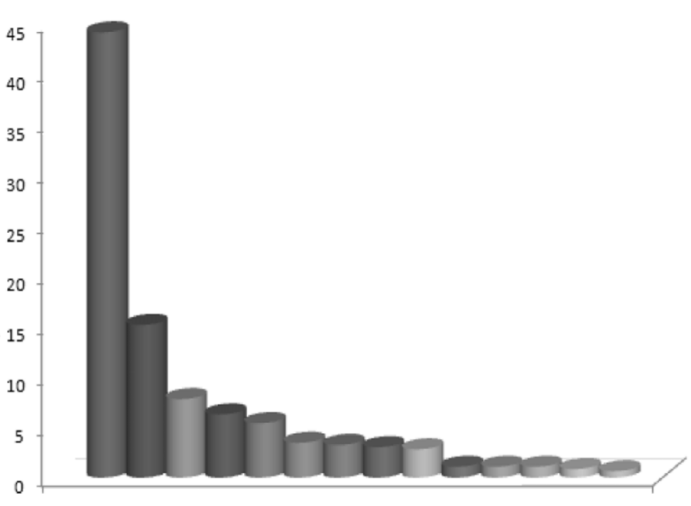

- Tanytarsus

a Polypedilum

m Cricotopus

aissimentum

a Chironomus

Coelotanypus

ablasbesmyia

- Cladopelma

aedokritus

- Calodomyia

asheum

Goeldichironomus

Nin Nilothauma

In Stenochironomus

Figure 2. A) Percentages of benthic macroinvertebrate taxa collected via Eckman-Birge grab. B) Percentages of individuals of the most abundant Chironomidae genera $(>1 \%)$ collected via Eckman-Birge grab.

1879), together representing $72.8 \%$ of the captures. The nonnative $P$. nattereri and $C$. piquiti were among the eight most frequently captured and were collected, respectively, in 36 and 34 of the 40 sampling sites. Two of the sites with the highest fish abundance were in the Santo Antônio tributary of the Quebra Anzol River. Similarly, two out of the four sites with greatest species richness were located in the river mouths of the Capivara and Santo Antônio tributaries.

Because there was insignificant correlation between the relative abundances of fish and macroinvertebrates with site geographical location (Macroinvertebrate $\mathrm{R}=-0.001, \mathrm{p}=0.57$; Fish $\mathrm{R}=-0.22, \mathrm{p}=0.99)$, we infer that there was no spatial autocorrelation among sites for abundance.

\section{Water and sediment character}

The $\mathrm{pH}$ and dissolved oxygen values indicated neutral to slightly alkaline (7.26 to 7.96) and well-oxygenated (6.4 to 10.1 $\mathrm{mg} / \mathrm{L})$ waters. All 40 sampling sites were classified as ultraoligotrophic $(\mathrm{TSI} \leq 47)$ (CETESB 2004); hence, there were no differences in trophic level among sites (Table 2). The sediments were mostly composed of fine sediments (sand, silt, and clay); in some sites we observed a predominance of larger particles (site numbers 10, 13, 22, 32, 37), such as pebbles and gravel (Table 2).

\section{Human disturbance}

Buffer land-use was dominated by natural grassland (34.1\%), natural forest (33.6\%), and agriculture $(21.7 \%)$, followed by pasture $(9.4 \%)$, bare soil $(0.9 \%)$, and residential development $(0.3 \%)$. The integrated disturbance index (IDI, Figure 3 ) shows a set of nine sites with low $(<0.2$ IDI) scores (site numbers $4,6,10,11,14,15,21,22,37$ ). These sites had buffers composed predominantly of natural vegetation. There were many moderately disturbed sites, and a set of four sites with high ( $>0.8$ IDI) scores (site numbers 2, 8, 38, 39), these sites had buffers dominated by pasture and agriculture. Only

Table 2. Abiotic values (average and standard deviation), granulometric composition (\%), and organic matter content (dry weight \%) and codes used in RDA (Redundancy Analyses) in Nova Ponte Reservoir.

\begin{tabular}{|c|c|c|c|}
\hline Variables & Means and standard deviations & Max & Min \\
\hline Cobbles \% (64 - $250 \mathrm{~mm})$ & $16.42 \pm 25.73$ & 87.3 & 0 \\
\hline Gravel $\%(2-63 \mathrm{~mm})$ & $8.59 \pm 15.38$ & 59.2 & 0 \\
\hline Coarse sand $\%(0.50-1 \mathrm{~mm})$ & $3.42 \pm 3.67$ & 14.9 & 0 \\
\hline Medium sand $\%(0.250-0.49 \mathrm{~mm})$ & $12.82 \pm 10.60$ & 34.4 & 0.05 \\
\hline Fine sand $\%(0.1-0.249 \mathrm{~mm})$ & $13.02 \pm 8.83$ & 28.9 & 0.03 \\
\hline Silt/clay $\%(<0.062 \mathrm{~mm})$ & $11.83 \pm 11.85$ & 47.7 & 0.14 \\
\hline Organic matter ( $\%$ D.W.) & $9.21 \pm 4.22$ & 17.1 & 2.25 \\
\hline Site Depth $(\mathrm{m})$ & $4.21 \pm 2.23$ & 12 & 1.2 \\
\hline Secchi Depth (m) SEC & $3.13 \pm 1.45$ & 7.7 & 1.2 \\
\hline Air temperature $\left({ }^{\circ} \mathrm{C}\right)$ & $29.22 \pm 2.86$ & 35 & 23 \\
\hline Water temperature $\left({ }^{\circ} \mathrm{C}\right)$ & $25.63 \pm 0.42$ & 26.4 & 24.7 \\
\hline $\mathrm{pH}$ & $7.56 \pm 0.19$ & 7.9 & 7.2 \\
\hline Conductivity $\left(\mu \mathrm{S} \mathrm{cm}^{-1}\right)$ & $22.8 \pm 4.21$ & 45 & 18 \\
\hline Total Dissolved Solids (TDS) $\left(\mathrm{mg} \mathrm{L}^{-1}\right)$ & $0.01 \pm 0.00$ & 0.029 & 0.011 \\
\hline Dissolved Oxygen (DO) $\left(\mathrm{mg} \mathrm{L}^{-1}\right)$ & $7.74 \pm 0.71$ & 10.1 & 6.3 \\
\hline Turbidity (Trb) (NTU) & $2.53 \pm 1.47$ & 7.2 & 1.1 \\
\hline Chlorophyll a $(\mathrm{Ch})\left(\mu \mathrm{g} \mathrm{L}^{-1}\right)$ & $0.88 \pm 0.41$ & 2.1 & 0.3 \\
\hline Total Nitrogen $(\mathrm{TN})\left(\mathrm{mg} \mathrm{L}^{-1}\right)$ & $0.05 \pm 0.01$ & 0.08 & 0.04 \\
\hline Total Phosphorus (TP) (mg L $\left.{ }^{-1}\right)$ & $0.01 \pm 0.00$ & 0.03 & 0 \\
\hline
\end{tabular}




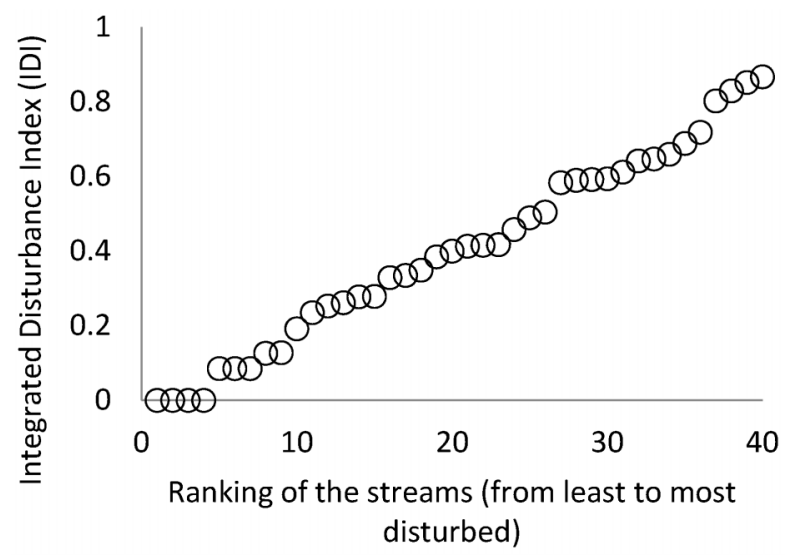

Figure 3. Integrated Disturbance Index (IDI) values for 40 Nova Ponte Reservoir sites. Sites with values close to 1 are most disturbed.

five alien macroinvertebrate and fish metrics were significantly related to disturbance as measured by the IDI (Table 3 ).

\section{Influence of water quality on biological assemblages}

Following redundancy analyses, we selected abiotic variables (Table 2) and 8 and 10 macroinvertebrate and fish metrics, respectively (Table 4) to enter into the RDA. The total variation explained by the first two RDA axes was 18\% (Axis 1 $=13 \%$, Axis $2=5 \%$ ). Axis 1 was positively related to Secchi depth and negatively related to total dissolved solids. Axis 2 was positively related to total nitrogen and negatively related to total phosphorus. Alien biotic metrics $\mathrm{D}, \mathrm{H}, \mathrm{M}$, and $\mathrm{P}$ were associated with greater dissolved oxygen (DO) concentrations and Secchi depths (Figure 4). The RDA separated two clusters of sites along a turbidity, total dissolved solids, total phosphorus and chlorophyll-a gradient. One of these clusters included sites mainly located in the central portion of the reservoir. In this region the ground cover was dominated by agriculture (sites 5, 6, 7, 8, 9, 26, 31, 33, 34, 35). At these sites there were greater concentrations of phosphorus, total solids and chlorophyll, and greater turbidity. Benthic macroinvertebrate groups considered resistant were related to the presence of these parameters in high concentrations ( $\mathrm{C}$ and $\mathrm{G}$, Figure 4). The second cluster of sites is located in the upper portion of the reservoir, and had mostly natural vegetation in their buffers $(13,14,15,18,19,22,24,28,29,30)$.

\section{Discussion}

Benthic macroinvertebrate assemblages are efficient tools for assessing ecological conditions of aquatic ecosystems (Callisto et al. 2005). In Nova Ponte Reservoir, we observed that sites with lower family richness were concentrated near the dam. Sites with greater family richness and individual abundances were located far from the dam. Sites where we collected Chironomus (Meigen 1803) and Goeldichironomus (Fittkau 1965) had abundant aquatic macrophytes and agriculture drainage. These genera prefer sites with greater sediment organic matter content and aquatic macrophytes (Barbosa \& Callisto 2001). Tanytarsus (van der Wulp 1984) was the most abundant genus, with a broad distribution in all regions of the reservoir. Because this genus has low blood hemoglobin concentration (Panis et al. 1996), it indicates environments with good water quality.

Ligeiro et al. (2013) indicated that the IDI is a good descriptor of disturbances at different spatial scales. With its implementation, we found that the Nova Ponte reservoir had mostly natural vegetation buffers and intermediate IDI values. However, some sample sites had high levels of agriculture, high values of IDI, and substantial numbers of non-native species. USEPA (2009) emphasized that lakes with poor cover and complexity of riparian and littoral habitat are approximately 3 times more likely to have poor biological integrity, likely because of habitat simplification and reduced riparian buffer protection from upland stressors. Human activities can alter environmental quality, reducing plant cover and physical habitat complexity in reservoir littoral zones (Molozzi et al. 2011, Kaufmann et al. 2014). According to Benedito-Cecílio et al. (1997), habitat modification directly influences such fish biological functions as diet, reproduction, and growth. Allan (2004) reported that watercourses draining croplands that had once been forests supported fewer macroinvertebrate and fish species than those draining forests. However, tools for the assessment of lentic systems have been poorly developed (Irz et al. 2008) and the influence of agriculture on the structure of reservoir aquatic assemblages has been poorly studied. Molozzi et al. (2011) assessed the influence of habitat structural complexity on benthic macroinvertebrate assemblages in three urban reservoirs in the Paraopeba River Basin, southeastern Brazil. They observed the highest richness of benthic organisms and the fewest non-native individuals in the reservoir with the greatest riparian complexity and the least littoral zone disturbance.

Of all the macroinvertebrate metrics examined, only three were significantly related to differences in disturbance among sites in the reservoir, and these were alien species metrics. One of the non-native mollusks recorded near the dam, Melanoides tuberculatus (Gastropoda: Thiaridae), is native to East Africa, Southeast Asia, China, and the Indo-Pacific Islands and is broadly distributed in Brazil (Silva \& Barros 2011). Its introduction may be related to the trade of ornamental plants and fish (Fernandez et al. 2003) and to control Biomphalaria glabrata (Say 1818), the intermediate host of Schistosoma

Table 3. Metrics significantly related to anthropogenic disturbance: results of simple regression analysis between biological metrics and the IDI (Integrated Disturbance Index).

\begin{tabular}{lccc}
\hline Metrics & P value & $\mathbf{r}$ & $\mathbf{r}^{\mathbf{2}}$ \\
\hline Abundance of alien benthic macroinvertebrate taxa & 0.01 & 0.42 & 0.18 \\
Percentage of alien benthic macroinvertebrate taxa & 0.03 & 0.35 & 0.12 \\
Richness of alien macroinvertebrate taxa & 0.02 & 0.38 & 0.14 \\
Percentage of alien fish species & 0.03 & 0.35 & 0.12 \\
Number of alien fish species & 0.03 & 0.35 & 0.12 \\
\hline
\end{tabular}


Table 4. Selected biotic metrics.

\begin{tabular}{|c|c|c|c|c|}
\hline & Code & Max & Med & Min \\
\hline \multicolumn{5}{|l|}{ Macroinvertebrates } \\
\hline Number of individuals & A & 158 & 27.9 & 1 \\
\hline Number of resistant individuals & $\mathrm{B}$ & 140 & 24.6 & 1 \\
\hline Percentage of resistant individuals & $\mathrm{C}$ & 98 & 86.1 & 19 \\
\hline Percentage of non-native individuals & $\mathrm{D}$ & 80 & 8 & 0 \\
\hline Number of EPT individuals & $\mathrm{E}$ & 12 & 1.1 & 0 \\
\hline Resistant organisms taxa richness & $\mathrm{F}$ & 2 & 1.6 & 1 \\
\hline Percent resistant taxa richness & $\mathrm{G}$ & 100 & 69.7 & 25 \\
\hline Percent non-native taxa richness & $\mathrm{H}$ & 66 & 8.6 & 0 \\
\hline \multicolumn{5}{|l|}{ Fish } \\
\hline Number of native species & I & 12 & 7.6 & 4 \\
\hline Number of non-native species & $\mathrm{J}$ & 4 & 2.3 & 0 \\
\hline Percent species representing $90 \%$ of abundance & $\mathrm{L}$ & 85.7 & 61.5 & 37.5 \\
\hline Percent non-native species richness & M & 37.5 & 24.3 & 11.1 \\
\hline Percent migratory species & $\mathrm{N}$ & 33.3 & 5.5 & 0 \\
\hline Percent native species abundance & $\mathrm{O}$ & 100 & 86.3 & 58.9 \\
\hline Percent non-native individuals & $\mathrm{P}$ & 66.8 & 19 & 0 \\
\hline Catch per unit effort of non-native species & $\mathrm{R}$ & 31.7 & 12.6 & 2.08 \\
\hline Abundance of rheophilic individuals & $\mathrm{S}$ & 1.8 & 0.2 & 0 \\
\hline
\end{tabular}

mansoni, as it is a possible competitor of the snail (Giovanelli et al. 2002). Another non-native mollusk collected, the bivalve Corbicula fluminea, also has a broad distribution in Brazil (Silva \& Barros 2011). That species has a Chinese origin and was introduced in the Americas for food (Suriani et al. 2007). One of the problems resulting from the introduction of these species is the obstruction of pipes in reservoirs and hydroelectric structures (Silva \& Barros 2011). In some sites, we observed Macrobrachium amazonicum (Palaemonidae, Decapoda). This species is broadly distributed in South
America, in the basins of the Orinoco, Amazonas, and Paraguay Rivers. Its type locality is the central basin of the Amazon River, in the region of Manaus (Silva et al. 2007).

Similar to macroinvertebrates, only two alien fish metrics were significantly related to differences in disturbance among sites in the reservoir. In Nova Ponte Reservoir, out of five introduced fish species, $P$. nattereri and $C$. piquiti stood out, for being collected in most sampling sites and for being the most abundant. The invasion of non-native species is currently considered the second highest cause of biodiversity loss at a

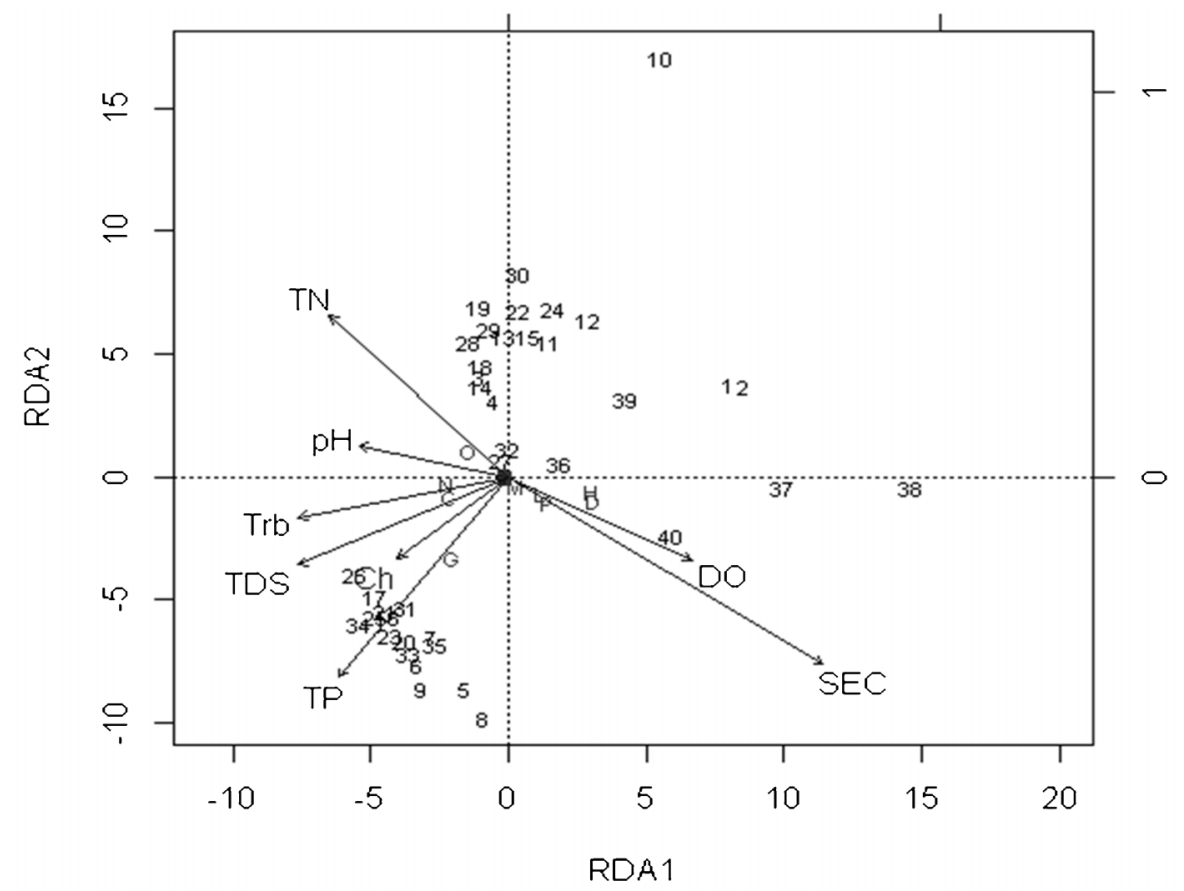

Figure 4. RDA ordination of 40 Nova Ponte Reservoir sites based on water quality. Numbers represent sampling sites, letter combinations represent water quality metrics (Table 3), single letters represent biological metrics (Table 4). 
global scale (Coradin \& Tortato 2006). These transformations are even more drastic in simplified biological environments, such as reservoirs and when the aliens are piscivores (Hughes \& Herlihy 2012). We observed greater native fish species richness and abundance close to the tributaries, which probably resulted from the tendency of the ichthyofauna to colonize sites with physical characteristics similar to the original lotic environment (Agostinho et al. 2007).

Some limnological characteristics were related to the presence of agriculture in the vicinity of some sampling sites. This activity degrades aquatic ecosystems by increasing the entry of pollutants, degrading physical habitat, reducing or completely removing riparian cover, and increasing nutrient concentrations to damaging levels (Allan, 2004). Otherwise, water quality and sediment variables varied little in our study. Homogeneity in physicochemical variables has been reported for other reservoirs also (Beltrão et al. 2009). Araújo \& Santos (2001) reported weak associations between abiotic parameters and the ichthyofauna. However, Beghelli et al. (2012) observed a relationship between macroinvertebrates and the trophic state index at different sampling sites in a reservoir in São Paulo state. That study indicated that the benthic macroinvertebrate assemblage responded to nutrient availability and dissolved oxygen concentration. Silva et al. (2006) related low correlations between fish abundance and limnological characteristics to a low susceptibility of fish to alterations in limnological characteristics. In contrast, several studies observed associations between abiotic variables and the distribution of the ichthyofauna in this type of environment (Oliveira et al. 2005, Prchalová et al. 2008). Some environmental variables are particularly associated with fish assemblages, such as depth (Prchalová et al. 2008), availability of littoral zone food and shelter (Vidotto \& Carvalho 2007), presence of aquatic vegetation (Pelicice et al. 2005, Abes \& Agostinho 2001), dissolved oxygen, temperature, pH, (Castro et al. 2003, Araújo et al. 2009), transparency (Petry et al. 2003) and conductivity (Rodríguez \& Lewis 1997). Distribution and abundance patterns of fish species in reservoirs can also be affected by other physical habitat attributes, such as type and size of substrate, presence of macrophytes or submerged vegetation, and type and integrity of riparian vegetation (Kaufmann et al. 2014).

We did not reject our hypothesis that macroinvertebrate and fish assemblages in the reservoir respond to habitat disturbance and water quality. Disturbances at multiple scales may alter natural patterns and processes, leading to environmental changes and damaging biological communities (Ligeiro et al. 2013). Our results reinforce the importance of assessing reservoir ecological conditions at several scales. The study of land use, littoral zone physical habitat, water quality, and assemblage structure set the ground for proposing actions to rehabilitate and conserve aquatic ecosystems (USEPA 2009).

Anthropogenic disturbances are important for defining priority sites for rehabilitation and conservation of ecological characteristics and aquatic biota. Based on our results we suggest further studies in the reservoir to test other explanations for the results observed, as well as to validate the initial assessment, according to the method described by USEPA (2011). Monitoring environmental quality is very important for hydroelectric enterprises responsible for managing a natural resource that has been modified by humans, is sensitive to alterations in time and space, and subjected to multiple competing uses.

\section{Acknowledgments}

The authors acknowledge P\&D ANEEL (GT-487) (Projeto de Pesquisa e Desenvolvimento da Agência Nacional de Energia Elétrica) and CEMIG (Companhia Energética de Minas Gerais) Programa Peixe Vivo for funding the project, CAPES (Coordenação de Aperfeiçoamento de Pessoal de Nível Superior), $\mathrm{CNPq}$ (Conselho Nacional de Desenvolvimento Científico e Tecnológico), FAPEMIG (Fundação de Amparo a Pesquisa do estado de Minas Gerais) and PROGRAD/UFMG (Pro-Reitoria de Graduação da Universidade Federal de Minas Gerais) for financial support. Special thanks to colleagues from the Laboratório de Ecologia de Bentos - UFMG. MC was awarded research productivity grant CNPq No. 302960/2011-2) and Minas Gerais researcher grant FAPEMIG PPM-00077/13. Reviews by Bianca Terra and 2 anonymous referees improved the manuscript. This manuscript was subjected to review by the National Health and Environmental Effects Research Laboratory's Western Ecology Division and approved for publication. Approval does not signify that the contents reflect the views of the Agency.

\section{References}

ABES, S.S. \& AGOSTINHO, A.A. 2001. Spatial patterns in fish distributions and structure of the ichthyocenosis in the Água Nanci stream, upper Paraná River basin, Brazil. Hydrobiologia. 445:217227, doi: http://dx.doi.org/10.1023/A:1017538720502

AGostinho, A.A., GOMES, L.C. \& PELICICE, F.M. 2007. A ictiofauna de reservatórios. In Ecologia e manejo de recursos pesqueiros em reservatórios do Brasil (A.A. Agostinho, L.C. Gomes \& F.M. Pelicice ed.) EDUEM, Maringá, p.70-105.

AGOSTINHO, A.A., PELICICE, F.M. \& GOMES, L.C. 2008. Dams and the fish fauna of the Neotropical region: impacts and management related to diversity and fisheries. Braz. J. Biol. 68:1119-1132, doi: http://dx.doi.org/10.1590/S1519-69842008000500019

ALLAN, J.D. 2004. Landscapes and Riverscapes: The Influence of Land Use on Stream Ecosystems. Annu. Rev. Ecol. Evol. Syst. 35:257-284, doi: http://dx.doi.org/10.1146/annurev.ecolsys.35.120202.110122

ARAÚJO, F.G. \& SANTOS, L.N. 2001. Distribution of fish assemblages in Lajes reservoir, Rio de Janeiro, Brazil. Braz. J. Biol. 61(4):563-576, doi: http://dx.doi.org/10.1590/S1519-69842001000400006

ARAúJO, F.G., PINTO, B.C.T. \& TEIXEIRA, T.P. 2009. Longitudinal patterns of fish assemblages in a large tropical river in southeastern Brazil: evaluating environmental influences and some concepts in river ecology. Hydrobiologia. 618:89-107, doi: http://dx.doi.org/10.1007/s10750-008-9551-5

BARBOSA, F.A.R. \& CALLISTO, M. 2001. Rapid assessement of water quality and diversity of benthic macroinvertebrates in the upper and middle Paraguay River using the Aqua-Rap approach. Int. Ver. Theor. Angew. 27(5):2688-2692.

BEAVAN, L., SADLER, J. \& PINDER, C. 2001. The invertebrate fauna of a physically modified urban river. Hydrobiologia. 455:97108, doi: http://dx.doi.org/10.1023/A:1017584105641

BEGHELli, F.G.S., DOS SANTOS, A.C.A., URSO-GUIMARÃES, M.V. \& CALIJURI, M.C. 2012. Relationship between space distribution of the benthic macroinvertebrates community and trophic state in a Neotropical reservoir (Itupararanga, Brazil). Biota Neotrop. 12(4):114124, doi: http://dx.doi.org/10.1590/S1676-06032012000400012

BELTRAO, G.B.M., MEDEIROS, E.S.F. \& RAMOS, R.T.C. 2009. Effects of riparian vegetation on the structure of the marginal aquatic habitat and the associated fish assemblage in a tropical Brazilian reservoir. Biota Neotrop. 9(4):37-43, doi: http:// dx.doi.org/10.1590/S1676-06032009000400003

BENEDITO-CECÍLIO, E., AGOSTINHO, A.A., JÚLIO JR. H.F. \& PAVANELLI, C.S. 1997. Colonização ictiofaunística do reservatório de Itaipu e áreas adjacentes. Rev. Bras. Zool. 14(1):1-14. 
BORGES, H., CASTRO, R., ALVES, A., RAMALHO, D., LIMA, E., QUEIROZ, A., MELO, V. \& SEVERI, W. 2010. Caracterização da comunidade de macroinvertebrados bentônicos no reservatório de Sobradinho e Submédio Rio São Francisco. In Reservatórios do nordeste do Brasil: biodiversidade, ecologia e manejo (A.N. MOURA, E.L. ARAÚJO, M.C. BITTENCOURT-OLIVEIRA, R.M.M. PIMENTEL \& U.P. ALBUQUERQUE eds.). Bauru-SP: Canal6, p. 479-502.

BRITSKI, H.A., SATO, Y. \& ROSA, A.B.S. 1986. Manual de identificação de peixes da região de Três Marias (com chaves de identificação para os peixes da bacia do São Francisco). $2^{\mathrm{a}}$ ed. CODEVASF, Brasília.

CALLISTO, M. \& ESTEVES, F. 1996. Composição granulométrica do sedimento de um lago amazônico impactado por rejeito de bauxita e um lago natural. Acta Limnol. Bras. 8:115-126.

CAllisto, M., GONÇAlves, J.F. \& MORENO, P. 2005. Invertebrados Aquáticos como Bioindicadores. In Navegando o Rio das Velhas das Minas aos Gerais (E.M.A. Goulart, ed), UFMG, Belo Horizonte, p. 555-567.

CASTRO, R.J., FORESTI, F. \& CARVALHO, E.D. 2003. Composição e abundância da ictiofauna na zona litorânea de um tributário, na zona de sua desembocadura no reservatório de Jurumirim, Estado de São Paulo, Brasil. Acta. Sci. Biol. Sci. 25(1):63-70, doi: http://dx.doi.org/10.4025/actascibiolsci.v25i1.2084

CARMOUZE, J.P. 1994. O metabolismo dos ecossistemas aquáticos: fundamentos teóricos, métodos de estudo e análises químicas. FAPESP, São Paulo.

CEMIG (Companhia Energética de Minas Gerais). Http://www.cemig. com.br/pt-br/a_cemig/Nossa_Historia/Paginas/Usinas_Hidreletricas. aspx. (Último acesso em 15/01/2003)

CETESB - Companhia de Tecnologia de Saneamento Ambiental, 2004. Relatório de Qualidade das Águas Interiores do Estado de São Paulo. CETESB, São Paulo, 264 p.

CLIMATEMPO, 2013. Climatologia de Nova Ponte - MG. http:// www.climatempo.com.br/climatologia/2789/novaponte-mg. (Último acesso em 15/04/2013)

CORADIN, L. \& TORTATO, D.T. 2006. Espécies exóticas invasoras: situação brasileira. Ministério do Meio Ambiente, Secretaria de Biodiversidade e Florestas, MMA, Brasília, 24p.

COSTA, C., I.D.E, S. \& SIMONKA, C.E. 2006. Insetos Imaturos Metamorfose e Identificação. Editora Holos, Ribeirão Preto.

DURÃES, R., POMPEU, P.S. \& GODINHO, A.L. 2001. Alimentação de quatro espécies de Leporinus (Characiformes, Anostomidae) durante a formação de um reservatório no sudeste do Brasil. Iheringia Sér. Zool. 90:183-191, doi: http://dx.doi.org/10.1590/ S0073-47212001000100019

ESTEVES, F.A., SUZUKI, M., CALLISTO, M.F.P. \& PERES-NETO, P.R. 1995. Teores de matéria orgânica, carbono orgânico, nitrogênio, fósforo e feopigmentos no sedimento de alguns ecossistemas lacustres do litoral do Estado do Espírito Santo. Oecol. Bras. 1:407416, doi: http://dx.doi.org/10.4257/oeco.1995.0101.20

FALK-PETERSEN, J., BOHN, T. \& SANDLUND, O.T. 2006. On the numerous concepts in invasion biology. Biol Invasions. 8:14091424, doi: http://dx.doi.org/10.1007/s10530-005-0710-6

FELD, C.K. \& HERING, D. 2007. Community structure or function: effects of environmental stress on benthic macroinvertebrates at different spatial scales. Freshw. Biol. 52:1380-1399, doi: http:// dx.doi.org/10.1111/j.1365-2427.2007.01749.x

FERNÁNDEZ, H.R. \& DOMINGUEZ, E. 2001. Guia para la determinación de los artrópodos bentônicos sudamericanos. Universidad Nacional de Tucumán, San Miguel de Tucumán.

FERNANDEZ, M.A., THIENGO, S.C. \& SIMONE, L.R.L. 2003. Distribuition of the introduced freshwater snail Melanoides tuberculatus (Gastropoda: Thiaridae) in Brazil. The Nautilus. 117(3):78-82.

FRANÇA, J.S. \& CALLISTO, M. 2007. Coleção de macroinvertebrados bentônicos: ferramenta para o conhecimento da biodiversidade em ecossistemas aquáticos continentais. Neotrop. Biol. Cons. 2(1):3-10.
FRANKLIN, K.L., DIETRICH, W.E. \& TRUSH, W.J. 1995. Downstream ecological effects of dams, a geomorphic perspective. Bioscience. 45(3):183-192, doi: http://dx.doi.org/10.2307/1312557

GEHRKE, P.C., GILLIGAN, D.M. \& BARWICK, M. 2002. Changes in fish communities of the Shoalhaven river 20 years after construction of Tallowa dam, Australia. River Res. Appl. 18:265286, doi: http://dx.doi.org/10.1002/rra.669

GIOVANElli, A., VIEIRA, M.V. \& SILVA, C.L.P.A.C. 2002. Interaction between the intermediate host of Schistosomiasis in Brazil Biomphalaria glabrata (Planorbidae) and a possible competitor Melanoides tuberculata (Thiaridae): I. laboratory experiments. Memórias do Instituto Oswaldo Cruz. 97(3):363-369, doi: http:// dx.doi.org/10.1590/S0074-02762002000300016

GOLTERMAN, H.L., CLYMO, R.S. \& OHMSTAD, M.A.M. 1978. Methods for physical and chemical analysis of freshwaters. IBP Handbook n.8, Blackwell: London.

GRAÇA, W.J. \& PAVANELLI, C.S. 2007. Peixes da planície de inundação do alto rio Paraná e áreas adjacentes. EDUEM, Maringá.

HAMMER, O., HARPER, D.A.T \& RYAN, P.D. 2003. PAST: Paleontological Statistics Software Package for Education and Data Analysis. Palaeontol. Electron., 4.

HUGHES, S.J., SANTOS, J.M., FERREIRA, M.T., CARAÇA, R. \& MENDES, A.M. 2009. Ecological assessment of an intermittent Mediterranean river using community structure and function: evaluating the role of different organism groups. Freshw. Biol. 54:2383-2400, doi: http://dx.doi.org/10.1111/j.1365-2427.2009. 02253. $\mathrm{x}$

HUGHES, R.M. \& HERLIHY, A.T. 2012. Patterns in catch per unit effort of native prey fish and alien piscivorous fish in 7 Pacific Northwest USA rivers. Fisheries 37:201-211, doi: http://dx.doi.org/ $10.1080 / 03632415.2012 .676833$

HUGHES, R.M., DUNHAM, S., MAAS-HEBNER, K.G., YEAKLEY, J.A., SCHRECK, C.B., HARTE, M., MOLINA, N., SHOCK, C.C., KACZYNSKI, X.X. \& SCHAEFFER, J. 2014. A review of urban water body rehabilitation and mitigation challenges and approaches: (1) Rehabilitation and remediation. Fisheries. 39:18-29, doi: http://dx.doi.org/10.1080/03632415.2013. 836500

IRZ, P., BORTOLI, J., MICHONNEAU, F., WHITTIER, T.R., OBERDORFF, T. \& ARGILLIER, C. 2008. Controlling for natural variability in assessing the response of fish metrics to human pressures for lakes in north-east USA. Aquat. Conserv. Marine and Freshwater Ecosystems. 18:633-646, doi: http:// dx.doi.org/10.1002/aqc. 859

KAUFMANN, P.R., PECK D.V., PAULSEN S.G., SEELIGER C.W., HUGHES R.M., WHITTIER T.R., \& KAMMAN, N.C. 2014. Lakeshore and Littoral Physical Habitat Structure in a National Lakes Assessment. Lake and Reservoir Management. 30(2):192-215, doi: http://dx.doi.org/10.1080/10402381.2014.906524

LEGENDRE, P. \& LEGENDRE, L. 1998. Numerical Ecology, Elsevier, Amsterdam.

LIGEIRO, R., HUGHES, R.M., KAUFMANN, P.R., MACEDO, D.R., FIRMIANO, K.R., FERREIRA, W.R., OLIVEIRA, D., MELO, A.S. \& CALLISTO, M. 2013. Defining quantitative stream disturbance gradients and the additive role of habitat variation to explain macroinvertebrate taxa richness. Ecol. Indic. 25:45-57, doi: http://dx.doi.org/10.1016/j.ecolind.2012.09.004

LUIZ, E.A., GOMES, L.C., AGOSTINHO, A.A. \& BUllA, C.K. 2003. Influência de processos locais e regionais nas assembléias de peixes em reservatórios do Estado do Paraná, Brasil. Acta. Sci. Biol. Sci. 25(1):107-114, doi: http://dx.doi.org/10.4025/actascibiolsci.v25i1.2087

MACEDO, D.R., POMPEU, P.S., MORAIS, L., CASTRO, M.A., ALVES, C.B.M., FRANÇA, J.S., SANCHES, B.O., UCHÔA, J. \& CALLISTO, M. 2014. Sampling site selection, land use and cover, field reconnaissance, and sampling. In: CALLISTO, M., HUGHES, R.M., LOPES, J.M. \& CASTRO, M.A. (eds), 
Ecological conditions in hydropower basins. Belo Horizonte: Companhia Energética de Minas Gerais, p. 61-83. (Série Peixe Vivo, 3).

MACEDO, D.R., LIGEIRO, R., FERREIRA, W.R., JUNQUEIRA, N.T., SANCHES, B.O., SILVA, D.R.O., ALVES, C.B.M., HUGHES, R.M., KAUFMANN, P.R., POMPEU, P.S., SANTOS, G.B. \& CALLISTO, M. 2012. Parâmetros biológicos e de habitats físicos para a avaliação de bacias no sudeste do Brasil. Ação Ambiental. 13:15-18.

MACKERETH, F.J.H., HERON, J. \& TALLING, J.F. 1978. Water analysis: some revised methods for limnologists. Freshwater Biological Association, Cumbria and Dorset, England.

MANTEL, N.A. 1967. The detection of disease clustering and a generalized regression approach. Cancer Res. 27:209-220.

MARONEZE, D.M., TUPINAMBÁS, T.H., FRANÇA, J.S. \& CALLISTO, M. 2011. Effects of flow reduction and spillways on the composition and structure of benthic macroinvertebrate communities in a Brazilian river reach. Braz. J. Biol. 71(3):639651, doi: http://dx.doi.org/10.1590/S1519-69842011000400008

MERRITT, R.W. \& CUMMINS, K.W. 1996. An introduction to the aquatic insects of North America. 3rd ed. Kendall/Hunt Publishing, DubuqueIowa.

MEYER, W.B. \& TURNER, B.L. 1994. Changes in land use and land cover: a global perspective. Cambridge University Press, New York.

MOLOZZI, J., FRANÇA, J.S., ARAUJO, T.L.A., VIANA, T.H., HUGHES, R.M. \& CALLISTO, M. 2011. Diversidade de habitats físicos e sua relação com macroinvertebrados bentônicos em reservatórios urbanos em Minas Gerais. Iheringia Sér. Zool. 101:191-199, doi: http://dx.doi.org/10.1590/S0073-47212011000200006

MUNGNAI, R., NESSIMIAN, J.L. \& BAPTISTA, D.F. 2010. Manual de identificação de macroinvertebrados aquáticos do estado do Rio de Janeiro. Technical Books Editora, Rio de Janeiro.

OLIVEIRA, E.F., GOULART, E. \& MINTE-VERA, C.V. 2003. Patterns of dominance and rarity of fish assemblage along spatial gradients in the Itaipu Reservoir, Paraná, Brazil. Acta. Sci. Biol. Sci. 25(1):71-78.

OLIVEIRA, E.F., MINTE-VERA, C.V. \& GOULART, E. 2005. Structure of fish assemblages along spatial gradients in a deep subtropical reservoir (Itaipu Reservoir, Brazil-Paraguay border). Environ. Biol. Fish. 72:283-304, doi: http://dx.doi.org/10.1007/ s10641-004-2582-5

PELICICE, F.M., AGOSTINHO, A.A. \& THOMAZ, S.M. 2005. Fish assemblages associated with Egeria in a tropical reservoir: investigating the effects of plant biomass and diel period. Acta Oecol. Int. J. Ecol. 27:9-16, doi: http://dx.doi.org/10.1016/j.actao.2004.08.004

PANIS, L.I., GODDEERIS, B. \& VERHEYEN, R. 1996. On the relationship between vertical microdistribuition and adaptations to oxygen stress in littoral Chironomidae (Diptera). Hydrobiologia. 318:61-67, doi: http://dx.doi.org/10.1007/BF00014132

PÉREZ, G.R. 1988. Guia para el estudio de los macroinvertebrados acuáticos Del Departamento de Antioquia. Fondo Fen. Colombia/ Colciencias, Antioquia.

PETRY, A.C., AGOSTINHO, A.A. \& GOMES, L.C. 2003. Spatial variation of the fish assemblage structure from the upper Rio Paraná floodplain, Brazil, in a dry year. Acta Limnol. Bras. 15(1):1-13.

PRCHALOVÁ, M., KUBEČKA, J., VAŠEK, M., PETERKA, J., SED'A, J., JŮZA, T., ŘÍHA, M., JAROLÍM, O., TUŠER, M., KRATOCHVÍL, M., ČECH, M., DRAŠTÍK, V., FROUZOVÁ, J. \& HOHAUSOVÁ, E. 2008. Distribution patterns of fishes in a canyon-shaped reservoir. J. Fish. Biol. 73:54-78, doi: http:// dx.doi.org/10.1111/j.1095-8649.2008.01906.x

R DEVELOPMENT CORE TEAM. 2008. R: A language and environment for statistical computing. R Foundation for Statistical Computing, Vienna.
RAPOSEIRO, P.M., COSTA, A.C. \& HUGHeS, S.J. 2011. Environmental factors - spatial and temporal variation of chironomid communities in oceanic island streams (Azores archipelago). Ann. Limnol.-Int. J. Lim. 47:325-338, doi: http://dx.doi.org/ 10.1051/limn/2011048

ROCHA, O., ESPINDOLA, E.L.G., RIETZLER, A.C., FENERICVERANI, N. \& VERANI, J.R. 2011. Animal invaders in São Paulo state reservoirs. Oecol. Aust. 15(3):631-642, doi: http:// dx.doi.org/10.4257/oeco.2011.1503.14

RODRÍGUEZ, M.A. \& LEWIS, W.M. 1997. Structure of fish assemblages along environmental gradients in floodplain lakes of the Orinoco river. Ecol. Monogr. 67:109-128, doi: http://dx.doi.org/ 10.1890/0012-9615(1997)067[0109:SOFAAE]2.0.CO;2

SILVA, A.R.M., SANTOS, G.B. \& RATTON, T. 2006. Fish community structure of Juramento reservoir, São Francisco river basin, Minas Gerais, Brazil. Rev. Bras. Zool. 23(3):832-840, doi: http://dx.doi.org/10.1590/S0101-81752006000300031

SILVA, M.C.N., FREDOU, F.L. \& FILHO, J.S.R. 2007. Estudo do crescimento do camarão Macrobrachium amazonicum (Heller,1862) da Ilha de Combú, Belém, estado do Pará. Amazônia - Ciência e Desenvolvimento. 2(4):85-104.

SILVA, E.C. \& BARROS, F. 2011. Macrofauna bentônica introduzida no Brasil: lista de espécies marinhas e dulcícolas e distribuição atual. Oecol. Aust. 15(2):326-344, doi: http://dx.doi.org/10.4257/oeco.2011.1502.10

STATSOFT, 2007. STATISTICA (data analysis software system), 8.0 ed.

STEVENS, D.L. \& OLSEN, A.R. 2004. Spatially balanced sampling of natural resources. J. Amer. Statist. Assoc. 99:262-278, doi: http:// dx.doi.org/10.1198/016214504000000250

SUGUIO, K. 1973. Introdução à sedimentologia. Ed. Edgard Blucher Ltda, São Paulo.

SURIANI, A.L., FRANÇA, R.S. \& ROCHA, O. 2007. A malacofauna bentônica das represas do médio Tietê e uma avaliação ecológica das espécies exóticas invasoras, Melanoides tuberculata e Corbicula fluminea. Rev. Bras. Zool. 24(1):21-32, doi: http://dx.doi.org/ 10.1590/S0101-81752007000100003

TRIVINHO-STRIXINO, S. 2011. Larvas de Chironomidae. Guia de identificação. Depto Hidrobiologia/Lab. Entomologia Aquática/ UFSCar, São Carlos.

TUNDISI, JG. \& MATSUMURA-TUNDISI, T. 2008. Limnologia. Oficina de Textos, São Paulo.

USEPA, 2009. National Lakes Assessment: a collaborative survey of the Nation's lakes., EPA 841-R-09-001. Office of Water and Office of Research and Development, Washington, DC.

USEPA. 2011. National Lakes Assessment. field operations manual. EPA 841-B-11-003. U.S. Environmental Protection Agency, Washington, DC.

VIDOTTO, A.P. \& CARVALHO, E.D. 2007. Composition and structure of fish community in a stretch of the Santa Bárbara River influenced by Nova Avanhandava Reservoir (low Tietê River, São Paulo State, Brazil). Acta Limnol. Bras. 19(2):233-245.

VON SPERLING, E., 2012. Hydropower in Brazil: overview of positive and negative environmental aspects. Energy Procedia. 18:110 - 118, doi: http://dx.doi.org/10.1016/j.egypro.2012.05.023

VONO, V. 2002. Efeitos de duas barragens sobre a estrutura da comunidade de peixes do rio Araguari (bacia do Alto Paraná, MG). Tese de doutorado, Universidade Federal de Minas Gerais, Belo Horizonte.

WINKLER, L.W. 1888. Die Bertimmung des im wasser gelösten Sauer-stoffs. Berichte der Deutschen Chemischen Gesellschaft. 21:2843-2854, doi: http://dx.doi.org/10.1002/cber.188802102122

ZAR, J.H. 1996. Biostatistical analysis. 3rd ed. Prentice Hall, New Jersey. 